\title{
ZYX Gene
}

National Cancer Institute

\section{Source}

National Cancer Institute. ZYX Gene. NCI Thesaurus. Code C92672.

This gene is involved in focal adhesion assembly. 